\title{
PERSPECTIVES ON ACCOUNTING AND FISCAL LAW OF CROWDFUNDING IN ROMANIA
}

\author{
David Delia, PhD \\ "Vasile Goldiș" Western University of Arad, Romania \\ david_delia2003@yahoo.com \\ Nicolaescu Cristina, PhD \\ "Aurel Vlaicu" University of Arad, Romania \\ cristina_nc2@yahoo.com
}

(Received January 2017; Accepted March 2017)

\begin{abstract}
This paper aims to analyse the accounting and fiscal regime of crowdfunding and the legal framework for such operations in Romania. Crowdfunding provides support to project developers by enabling them to access finance in a simple and inexpensive manner. Thus we refer to the following: current state of crowdfunding operations and existing legal background for conducting such operations in Romania as well as possible directions for its improvement. We will also highlight the accounting and fiscal issues encountered by both companies that hold online crowdfunding platforms and those benefiting from the sums collected through this financing method. This paper is based on case study research method. Considering the fact that in Romania the functioning of the crowdfunding platforms is not yet regulated, the information and views set out in this article are those of the authors.
\end{abstract}

Keywords: crowdfunding; draft legislation; accounting treatments; fiscal treatments; legal entity;

JEL Codes: G21, M13, M41, K22

\section{Introduction}

In Romania crowdfunding is a relatively new type of economic operation. The lack of specific legislation in force poses challenges for the conceptual interpretation and for the accounting and fiscal treatment of the transactions performed by the stakeholders.

Crowdfunding is an alternative financing operation that provides the possibility for the holder of a project idea to collect a sum of money from a large number of investors who consider that the project idea is a viable business venture and want to support it financially.

Three types of stakeholders are involved within a crowdfunding operation: the holder of a project idea- the beneficiary of funds; the person who support financially the project idea- the investor; and the holder of an online platform by which the two aforementioned stakeholders are connected and that keeps the funds until the agreed conditions are fulfilled. Two situations may arise: (1) if the total 
David D., Nicolaescu C. (2017)

Perspectives on accounting and fiscal law of crowdfunding in Romania

estimated funds for the implementation of the project have not been collected entirely, the investors receive their money back; or (2) if the estimated funds have been collected entirely and the project fails, the funds invested are non-refundable. All terms and conditions of crowdfunding operations are established by the holders of the online platforms and are made available to the public.

Financing obtained in this way is cheaper and quicker as it removes substantial parts of the difficult procedure required to obtain funding by conventional means.

Depending on the nature of the project, investors can receive in return for their contributions various products and services; hence it may appear discussions on accounting and fiscal treatment of these generated transactions.

The way is perceived in Romania this idea of financing is the basis of our research. The paper presents the views of the authors on the accounting and fiscal treatment of crowdfunding operations in Romania from the perspective of the potential adoption of the Draft Law No. 801/2015 on the development of participatory financing (crowdfunding) both at the level of companies that hold online platforms for participatory financing and those benefiting from the sums collected through this financing method. From this starting point we will assess the advantages and the disadvantages posed to the stakeholders by this financing method.

The purpose of this paper is to answer at the following questions:

1) What is the current state of crowdfunding operations in Romania?

2) To what extent the Draft Law No. 801/2015 on the development of participatory financing (crowdfunding) creates favourable conditions for financing start-up initiatives?

3) What are the limitations of the Draft Law No. 801/2015 in the context of its potential application to the internationally recognised forms of crowdfunding?

4) Is there a need to improve the Draft Law No. 801/2015?

5) What are the accounting and fiscal implications for the stakeholders involved in crowdfunding operations in Romania?

\section{Conceptual landmarks of crowdfunding}

Crowdfunding (Mihai, 2014) is one of the most interesting ways to obtain funding for a project idea from the community/friends/ strangers or any other persons who truly believe in your idea.

Crowdfunding, in short, involves obtaining funding for various projects from community members (Artenie, 2014).

In literature the term crowdfunding is considered to be a subcategory of crowdsourcing both at national and conceptual level. Crowdsourcing is a process that involves outsourcing some activities to a distributed group of people. These 
persons represent an undefined public and are not employees of a specific organization.

Kaltenbeck (2011) identified four types of crowdsourcing as shown in Fig. 1. The term crowdsourcing was coined by journalist Jeff Howe who illustrated it in various examples in his articles published in Wired Magazine. Jeff Howe identified three categories of crowdsourcing: crowdcreation, crowdvoting and crowdwisdom (Howe, 2006). In addition, Kaltenberg added a fourth category of crowdsourcing which is opposed to the previous three categories in the sense that it does not refer to aggregating knowledge, opinions or creativity, but it focuses on how to increase funding (fundraising).

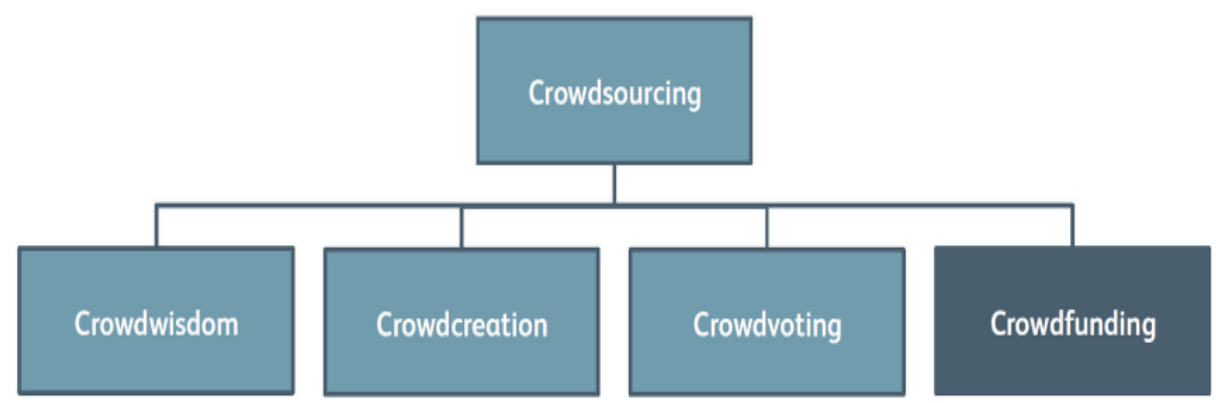

Source: Overview of the term crowdsourcing (Kaltenbeck, 2011)

The four types of crowdsourcing can be defined as (Dietrich A., Amrein S, 2016):

- Crowdwisdom refers to the use of the intelligence of community in the sense that it requires its activation and reflection in its knowledge.

- Crowdcreation reflects the creative potential of the community used in various forms: messages, audio files, various illustrations.

- Crowdvoting uses opinions and judgements of the groups to evaluate ideas and various contexts. The structured opinions within these processes serve as a base for decisions taken by groups. Crowdvoting can be used most often as a forecasting tool.

- Crowdfunding involves using the Internet as a key element. In contrast with the other categories, crowdfunding is not focused on the knowledge and the creative potential, but rather on the potential growth of funds for various project ideas.

According to A. Dietrich and S. Amrein (2016), crowdfunding as a way of financing online projects can be divided in four categories taking into account the consideration received as a key criterion:

DE GRUYTER OPEN
Studia Universitatis "Vasile Goldis" Arad. Economics Series Vol 27 Issue 1/2017 ISSN: 1584-2339; (online) ISSN: 2285 - 3065 
David D., Nicolaescu C. (2017)

Perspectives on accounting and fiscal law of crowdfunding in Romania

- Participatory financing based on equity (crowd-investing) which consists in selling a share part of the share capital of the company to several investors in exchange with the investment. In this situation investors become shareholders, expecting profit in the form of dividends.

- Reward-based crowdfunding which identifies with the situation where investors make donations for the project and expect in return non-financial rewards such as goods or services.

- Crowd-donating refers to the fact that persons donate small amounts of money for a charity project without expecting a reward in return.

- Crowd lending consists in lending a company that will repay the amount borrowed with interest. This type of financing can be assimilated to the traditional loan provided by a credit institution.

The illustration of this concept can be seen in the table below:

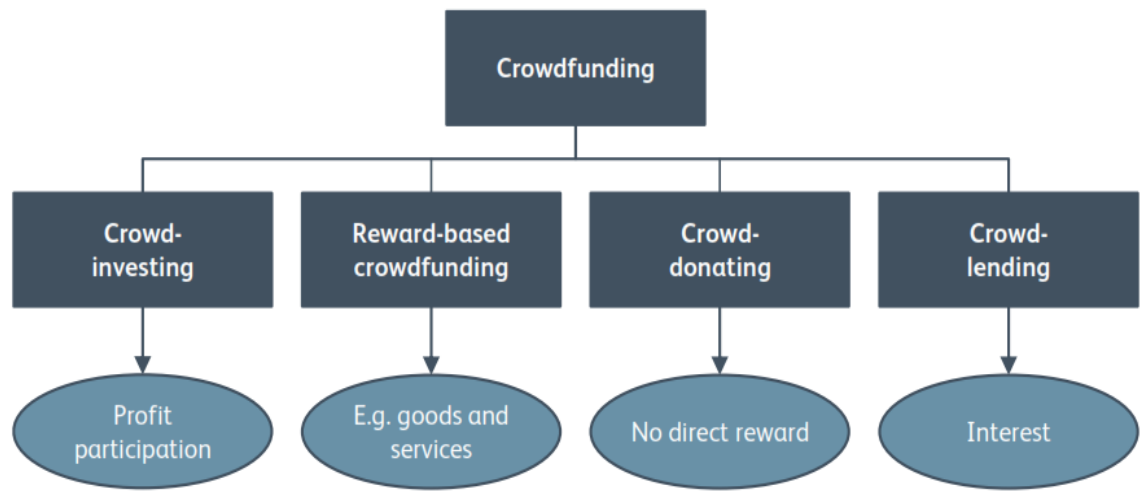

Source: Dietrich A., Amrein S, Crowdfunding monitoring Switzerland, 2016

\section{Literature review}

Even though many studies regarding the concept of crowdfunding can be found in literature, a detailed analysis regarding the accounting and fiscal implications of crowdfunding operations can rarely be found in scientific papers. Schwienbacher and Larralde (2010) offered the first description of the concept of crowdfunding which includes a case study focused on a French music-creation start-up that was intended to serve as a theoretic model to individuals wanting to use such a form of financing.

Agrawal et al (2010) used the music market seeking crowdfunding to understand if there are geographical constraints for the collection of these types of funds which 
are usual for the venture capital firms. In other working paper Burtch et al (2011) analized how timing and exposure affected 100 pitches for new journalism stories. Navneet B., Rai S.K. (2015) presents a case study that refers to applying the concept of crowdfunding in the Indian film industry. Taking into account the specific legislation of this country, the author analyses the best option from the beneficiary point of view.

Dietrich and Amrein (2016) explains in detail the concept of crowdfunding with reference to the existing financing platforms in Switzerland and makes remarks to the fiscal matters regarding the parties involved in financing.

Also T. Artenie (2014) presents in his article the concept of crowdfunding and its potential financial implications for the the users in Romania.

What we propose in this article is to highlight the approach to accounting and fiscal implications both at the level of companies holding online platforms for participatory financing (crowdfunding) and companies benefiting from the amounts raised through this manner of financing.

Although there is no specific legislation for crowdfunding in Romania, around 8 online platforms operate in this country (Crestemidei.ro, Kazuu.ro, Multifinantare.ro, PotSiEu.ro,We-are-here.ro, Bursabinelui.ro, Crowdfunding oferit de Universitatea Babeș-Bolyai din Cluj Napoca, Sprijină.ro ). These online platforms are non-profit organizations and support mostly social and/or humanitarian projects and the beneficiaries of the financing are individuals.

As it has already been mentioned, our research focuses on the accounting and fiscal challenges in light of implementation of the Draft Law on the development of participatory financing (crowdfunding) initiated in September 2015 in Romania.

The Draft Law as it was made available for public consultation refers only to two of the four forms of crowdfunding recognized at international level, namely: crowdlending (loan-based crowdfunding) and crowdinvesting (equity-based crowdfunding). It does not include crowd-donating (donation-based crowdfunding) or reward-based crowdfunding. The content of this draft law refers to direct investments which are made at the request of some project developers and that have to meet some certain requirements in order to be assimilated to participatory financing, such as:

- investors expect to make a profit from the investment of capital;

- projects are initiated by a project developer who is a legal person;

- funding is for a specific, clearly defined and limited project;

- funding is made through one of the forms specified by law;

Forms through which participatory financing of the projects can be made:

- issuance of securities (shares) or bonds (in case of joint-stock companies);

- issuance of debt instruments which gives investors the right to charge interest. 
David D., Nicolaescu C. (2017)

Perspectives on accounting and fiscal law of crowdfunding in Romania

As a consequence, those investing in projects financed through an online platform can become either associates/shareholders of the companies that proposed the project or creditors that expect to receive interest for the invested capital from the companies that proposed the project;

From the perspective of the companies that hold online platforms for participatory financing, these are obliged to fulfill the requirements set by A.S.F (Autoritatea de Supraveghere Financiară- Financial Supervisory Authority) and to register to C.N.V.M (Registrul Comisiei Naționale a Valorilor Mobiliare - The Register of the National Commission for Transferable Securities) stipulated in Law 297/2004 on the capital market. The register is public and until the registration is not performed the platform cannot manage any activity for participatory financing. These platforms have to obtain the status of company according to the Law 31/1990 in the sense that they have to prove their logistic and financial capacity to ensure operation of the platform (the minimum share capital is EUR 25,000) and the moral probity of its owners. Thus, the platforms constituted as non-governmental organizations will no longer be considered crowdfunding platforms and as such will not be able to manage this type of activity. The maximum amount of funds collected for each project may not exceed the equivalent in LEI of EUR 1,000,000 at the National Bank of Romania's exchange rate of the day posting the project.

The project developers or the beneficiaries of the financing are also conditioned to meet the following requirements:

- must be registered as a legal entity in Romania which means that individuals cannot benefit from this type of financing for their projects;

- to be published on such a platform, the project developer must submit to the account of the platform at least $5 \%$ of the value of the project from own funds. As a consequence, a developer cannot be able anymore to receive the whole amount estimated for the implementation of the project.

It is also mentioned in the Draft Law that no investor can invest more than EUR 1,000 in the same project on the same platform and more than EUR 5,000 in all projects published by that platform in a period of 12 months.

Both platforms and individuals/companies that conduct activities via these platforms can be monitored, controlled and sanctioned by A.S.F (Autoritatea de Supraveghere Financiară - Financial Supervisory Authority).

\section{Research Methodology}

This paper is the result of deductive reasoning, from theory to practice, with some inclinations towards inductive reasoning consisting of practical case studies designed to verify the extent to which certain theoretical aspects mentioned above are validated in practical terms. 
David D., Nicolaescu C. (2017)

Perspectives on accounting and fiscal law of crowdfunding in Romania

It is worth mentioning that these case studies are hypothetical and their suggested accounting and fiscal treatment represents the views of the authors of this article as long as the functioning of the crowdfunding platforms is not regulated yet in Romania. The accounting role is to provide the necessary information in order to take decision regarding the financial position, the performances and the changes in the financial position of the economic entity (Cernușca \&all, 2016).

In order to fulfill the objectives of the paper, wich was mention above, at the Introduction chapter, a range of research techniques and procedures were used in order to illustrate more clearly the results obtained:

- $\quad$ study of the literature in the field;

- study of the crowdfunding platforms and their terms for operation in Romania;

- analysis of the Draft Law No. 801/2015 on the development of participatory financing (crowdfunding);

- gathering and processing data from existing regulations in Romania, preparing the accounting formulas and analysing the fiscal implications of crowdfunding operations for the national budget;

- analysis of various studies on crowdfunding conducted in the field;

The study analyses the impact of crowdfunding operations both at the level of companies that hold online platforms for participatory financing and those benefiting from the sums raised through this financing method. Therefore this paper does not consider the situations where projects have a social or humanitarian nature and are connected with foundations, associations or other nonprofit organizations.

This study focuses on crowdlending (i.e. Loan-based crowdfunding) on the assumption that- given the current configuration of financial markets in Romaniathis operation will probably be the most popular form of crowdfunding.

For a better illustration of the case we take the example of the joint-stock company The Initiative which registers as a platform for participatory financing and receives the approval from A.S.F (Autoritatea de Supraveghere Financiară - Financial Supervisory Authority) to manage online operations.

The main services offered by the platform are:

- receiving and publishing financeable projects on the platform;

- ensuring the link between the potential investors and the project proponents;

- collecting the sums from investors and transfer them at the end of the bid to the project developers if the estimated funds have been collected entirely or return them to the investors if the total estimated funds for the implementation of the project have not been collected entirely (the platform applies a policy of "all or nothing" which means that are funded only those projects that collect the full amount requested).

Studia Universitatis "Vasile Goldis" Arad. Economics Series Vol 27 Issue 1/2017 ISSN: 1584-2339; (online) ISSN: 2285 - 3065

Web: publicatii.uvvg.ro/index.php/studiaeconomia.Pages $1-14$ 
David D., Nicolaescu C. (2017)

Perspectives on accounting and fiscal law of crowdfunding in Romania

The platform charges a commission for the above mentioned services from the amount collected which differs depending on their complexity - a greater commission is charged in the case of financing that involves issuance of equity securities.

In addition to these services, the platform offers for a fee other services such as assistance and advice on participatory financing - models of forms and contracts, advertisement for projects etc.

Following the launch of the online crowdfunding platform The Initiative, the jointstock company operating the platform is contacted by the company Cuptorul de Aur- a limited liability company with one shareholder which has as main activity manufacturing and marketing of bread and other bakery products. Cuptorul de Aur turned to the platform in hopes of obtaining the necessary funds for the purchase of new equipment in order to develop the existent business. It is worth mentioning that Cuptorul de Aur has an ongoing bank credit and a further request for a new credit would not be satisfactory due to the high interest. As it is about a stable and promising business and the scope of financing is the investment in new equipment, the owner opted for crowdlending.

Cuptorul de Aur decides to request 100,000 lei. According to the Draft Law No. $801 / 2015$ on the development of participatory financing (crowdfunding), the project developer- in this case Cuptorul de Aur - must lodge a guarantee of at least $5 \%$ of the total estimated value of the project from its own funds, namely 5,000 lei. Once the loan evaluation team assigned by the platform reviewed all the documents provided by the applicant, it is decided the approval of the launch of the project on the platform and the duration of this collecting bid is set at 20 days.

To succeed in attracting as many investors Cuptorul de Aur produced an advertising clip for popularizing the project. This advertising clip costed 2,000 lei to which was added the VAT rate of $19 \%$. Once launched on the platform, this advertising clip is very well received by the public and its feedback demonstrates the viability of the project.

After the approval to launch the project on the platform is obtained, the proposal submitted by Cuptorul de Aur is listed on the market and investors can bid for it.

Although the amount was raised in a period less than 20 days, Cuptorul de Aur has decided to wait for the entire period which ultimately led to an interest rate of $10 \%$ - much lower than that offered by the banking system.

At the end of the bidding period the platform transferred the amount raised from the collecting account to the account of Cuptorul de Aur and issued an invoice for the services rendered which is subsequently settled through bank transfer.

After receiving the funds in the bank account, Cuptorul de Aur can make its proposed investment and is obliged to repay the loan over a period of 5 years with 
an annual interest of $10 \%$. The loan has to be repaid by Cuptorul de Aur through bank transfer to the operator of the online crowdfunding platform which in turn has to transfer the amounts to investors.

The operations that will be further analyzed in terms of accounting and fiscalization are:

a) at the level of Cuptorul de Aur

- submission of a guarantee of 5\%;

- record of expenditure on the creation of the advertising clip;

- receipt of funds collected through the online crowdfunding platform;

- receipt of invoice from the online crowdfunding platform;

- payment of invoice issued by the online crowdfunding platform;

- payment of interest on funds collected through the online crowdfunding platform;

b) at the level of the online crowdfunding platform:

- receipt of a guarantee of 5\% from the total estimated value of the project;

- collection of funds from investors;

- transfer of funds to the project developer;

- invoicing services;

- collection of payment for the services;

- receiving the funds from the project developer to pay investors;

- transfer of funds to investors.

\section{Result and discussion:}

\subsection{Registration of operations in the accounting of the project developer}

Since the amount required to finance the project is 100,000 lei, the security lodged is supposed to be 5,000 lei. Submission of the guarantee involves transferring 5,000 lei from the account of Cuptorul de Aur to the account opened for this purpose by the online crowdfunding platform. Being a guarantee this transfer will be recognized in the accounting of Cuptorul de Aur as a claim. As the duration of this collecting bid is set at 20 days, the claim will be a short-term one and as a consequence, it will be recognized in a distinct analytic of the account 461 "Sundry debtors". In these conditions the accounting formula of the operation will be:

$$
\text { 461.0x "Sundry debtors" = } 5121 \text { "Bank accounts in lei" } \quad 5.000
$$

Recognition of expenses with advertising clip will be done in the analytic advertising expenditures of the account 623"Expenses on protocol, advertising and publicity": 
David D., Nicolaescu C. (2017)

Perspectives on accounting and fiscal law of crowdfunding in Romania

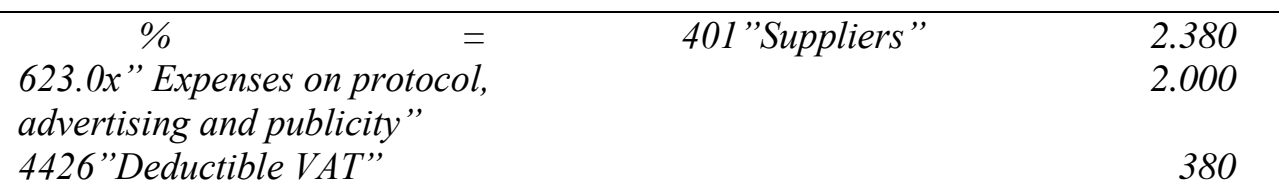

Once the amount requested was collected in the account opened for this purpose by the online crowdfunding platform, the transfer is made to the bank account of Cuptorul de Aur. As the chosen form of financing is crowdlending, the funds collectedd will be recognised as long-term debt in a distinct analytic of the account 167 "Other loans and associated liabilities".

$$
5121 \text { "Bank accounts in lei" = } \quad \begin{array}{r}
167.0 x \text { "Other loans and } \\
\text { associated liabilities" }
\end{array}
$$

Receiving back the security lodged of 5,000 lei:

$$
5121 \text { "Bank accounts in lei" = } \quad \text { 461.0x "Sundry debtors" } 5.000
$$

Since the amount collected by the platform is 100,000 lei, the online crowdfunding platform charges 6,000 lei to which is added the VAT rate of $19 \%$ and Cuptorul de Aur records the invoice in its accounting by the following formula:

$$
\begin{aligned}
& \% \text { = 401"Suppliers" } 7.140 \\
& 628 \text { "Expenses on services provided by third parties" } 6000 \\
& \text { 4426"Deductible VAT" } 1.140
\end{aligned}
$$

Payment of the invoice:

$$
401 \text { "Suppliers" = = } 5121 \text { "Bank accounts in lei" } 7.140
$$

According to the planned reimbursement of the loan, the rates along with the associated interest is paid regularly in the collection account of the online crowdfunding platform and subsequently from this account will be paid each investor according to its contribution to the loan:

$$
\begin{aligned}
& \% \\
& \text { 167.0x "Other loans and associated liabilities" = } \\
& 666 \text { "Interest expenses" }
\end{aligned}
$$


David D., Nicolaescu C. (2017)

Perspectives on accounting and fiscal law of crowdfunding in Romania

The fiscal implications at the level of the project developer refers to the impact of the operations generated by the processing of the participatory financing on taxes owed by Cuptorul de aur to the national budget, namely income tax and VAT.

Regarding the income tax it can be noted that this method of financing generates expenses that do not raise issues of deductibility with the exception of interest expenses. According to the art. 27, paragraph 1 of Law 225/2015 on the Fiscal Code, interest expenses are fully deductible only if the indebtedness of capital is lower or equal to 3. Regarding VAT, the operations generate only deductible VAT (VAT regime is not considered at collection) due to the acquisition of services.

\subsection{Registration of operations in the accounting of the participatory financing platform}

The first operation conducted by the participatory financing platform is to collect into its bank account the guarantee of 5,000 lei submitted by the project developer. Because the amount received does not belong to the platform, the operator of the participatory financing platform will register the sum as a short-term debt in a distinct analytic of the account 462 "Sundry creditors":

$$
5121 \text { "Bank accounts in lei" }=462.0 x \text { "Sundry creditors" } \quad 5.000
$$

To process the proposal for financing of the project developer Cuptorul de Aur, the participatory financing platform opens a collecting account (C.A) in a bank operating in Romania. This collecting account will record the amounts raised from investors during the 20 days set as the duration of this collecting bid:

\section{C.A "Bank accounts in lei" $=462.0 x$ "Sundry creditors" 100.000}

After the total amount is collected, the participatory financing platform transfers the amount to the account of the project developer and returns its security lodged:

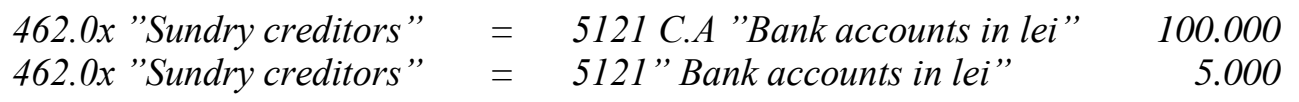

The participatory financing platform invoices the services provided to Cuptorul de Aur (ie 6\% fee applied to the outstanding balance):

\begin{tabular}{|c|c|}
\hline 4111 "Customers" & $\begin{array}{l}= \\
704 \text { "Income from provided services" } \\
4427 \text { "VAT collected" }\end{array}$ \\
\hline
\end{tabular}

DE GRUYTER OPEN
Studia Universitatis "Vasile Goldis" Arad. Economics Series Vol 27 Issue 1/2017 ISSN: 1584-2339; (online) ISSN: 2285 - 3065

Web: publicatii.uvvg.ro/index.php/studiaeconomia.Pages $1-14$ 
David D., Nicolaescu C. (2017)

Perspectives on accounting and fiscal law of crowdfunding in Romania

and collects this amount in its current account:

$$
5121 \text { "Bank accounts in lei" = } \quad 4111 \text { "Customers" } 7.140
$$

Receiving the payments from the project developer representing rates and associated interest along with their transfer to the investors according to their contribution to the loan generates the same type of accounting operations as in the collection, respectively transfer of the initial funds for the financing of the project (through accounts 462.0x "Sundry creditors" and 5121 C.A "Bank accounts in lei").

In terms of fiscal regime applied, the operations conducted by the participatory financing platform will generate taxable income from provided services, recorded when invoicing and VAT collected on the income.

\section{Conclusions}

Crowdfunding type of financing could represent a new option for start-up businesses in Romania, especially for those that have viable projects and do not have sufficient capital to implement them.

Although this type of financing is not regulated yet in Romania, at present there is a legislative project tackling this issue, i.e. the Draft Law No. 801/2015 on the development of participatory financing (crowdfunding) in Romania. As detailed above, this legislative project is not designed legally and fiscally to encourage and support crowdfunding operations. On the contrary, if the law is to be promulgated in its current shape, it can create difficulties for all interested investors to turn to this form of financing.

According to the authors, the limitations of this draft law are as follows:

- it is designed only for legal persons and does not offer the possibility for individuals to benefit from such financing for their projects;

- the investors are not allowed to invest more than EUR 1,000 in the same project hosted by the same platform and more than EUR 5,000 in all the projects hosted by the same platform within a period of 12 months;

- for a project to be published on such a platform, the project developer is subject to a security lodged of 5\% from the total estimated value of the project which must be transferred in the collecting account of the online crowdfunding platform until the bidding period is ended. If the project developer is unable to transfer this amount, it will lose the chance of being funded;

- there are only two ways of obtaining participatory financing for the projects: issuance of securities (shares) or bonds (in case of joint-stock companies), 
David D., Nicolaescu C. (2017)

Perspectives on accounting and fiscal law of crowdfunding in Romania

respectively issuance of debt instruments which gives investors the right to charge interest;

To create favorable conditions for financing crowdfunding projects in Romania, we consider that the Draft Law No. 801/2015 on the development of participatory financing (crowdfunding) should be improved as follows:

- access to financing on the online crowdfunding platforms should be available both for individual and legal entities;

- there should be no limitations on the amounts that investors are willing to invest in crowdfunding projects;

- should include forms of financing such as crowd-donating and reward-based crowdfunding. The main reason behind this action to be taken is that the vast majority of the crowdfunding platforms currently operating in Romania are based on the principles of these forms of financing;

- project developers should not be subject to a security lodged of 5\% to access this type of financing;

In conclusion, the Draft Law No. 801/2015 on the development of participatory financing (crowdfunding) in its current form is not favorable nor supports the initiative of people who want to participate in the crowdfunding process.

Crowdfunding operations pose no particular challenges in terms of accounting and fiscal treatment. As it could be noticed, the accounting records have been prepared under the existing legislation both at the level of project developer and the online crowdfunding platform: OMFP 1802/2014 and Republished Accounting Law $82 / 1991$. These operations are based from the fiscal point of view on the provisions of the current Fiscal Code in force, both at the level of project developer and online crowdfunding platform, and its fiscal implications refer to profit tax, respectively value added tax.

\section{Bibliography:}

1. Agrawal A., Catalini C, Goldfarb A(2010) - The geography of crowdfunding, SSRN Electronic Journal, Retrieved from https://www.researchgate.net/ publication 1228234410_The_Geography_of_Crowdfunding; XXXXXAccessed 8.10.2016].

2. Artenie T, (2014), Regimul fiscal al operațiunilor de crowd -funding, Revista TaxMagazine, nr.3 Noiembrie, pp.2- 15.

3. Burtch, Ghose A., Wattal S (2011) - An empirical examination of the antecedents and consequences of investement patterns in crowd-funded markets, SSRN Electronic Journal Retrieved from https://www.researchgate.net/ publication/ 228210682_ An_ Empirical_Examination_of_the_Antecedents_and_Consequences_of_Investment_Patte rns_in_Crowd-Funded_Markets; XXXXXAccessed 12.11.2016].

4. Cernuşca L., David D., Nicolaescu C., Gomoi B.,(2016), Empirical Study on the creative accounting, Studia Universitatis Vasile Goldiş, Arad, Economics Series Vol 26 Issue 2/2016, pp.64. 
David D., Nicolaescu C. (2017)

Perspectives on accounting and fiscal law of crowdfunding in Romania

5. Dietrich, A., Amrein S. (2016), Crowdfunding Monitoring Switzerland, Institute of Financial Services Zug IFZ, Retrieved from www.hslu.ch/crowdfunding; XXXXXAccessed 9.10.2016].

6. Howe, J. (2006), The Rise of Crowdsourcing. Wired Magazine.Issue 14.06 Retrieved from https://www.wired.com/2006/06/crowds/;XXXXXAccessed 23.11.2016].

7. Mihai L,(2014) - Ghidul tău în educație financiară Retrieved from http://laurentiumihai.ro/crowdfunding-din-romania/; XXXXXAccessed 2.11.2016].

8. Navneet B., Rai S.K. (2015), Lucia: What an Incredible Dream to Dream, 115-031-1, The Case Center.

9. Kaltenbeck, J. (2011), Crowdfunding und Social Payments, Berlin: Verlag epubli GMBH, Retrieved from http://13t.eu/oer/images/crowdfunding.pd XXXXXAccessed 10.11.2016].

10. Schwienbacher A., Larralde B.(2010) - Crowfunding of small antrepreneurial ventures, SSRN Electronic Journal (2010) Retrieved from http://www.ema.eu/ fileadmin/ content/REALISE_IT_ 2 /REALISE_ IT_3/ CROWD_ OUP _Final_Version.pdf; XXXXXAccessed 25.11.2016].

11. PL-X nr.801/2015 Proiect de Lege privind dezvoltarea finanțărilor paricipative (crowdfunding) Retrived from http://www.cdep.ro/ pls/proiecte/upl _pck.proiect?idp =14923; XXXXXAccessed 5.09.2016].

12. Legea contabilității nr.82/2001 republicată în 2008, M.Of nr.454/2008.

13. OMFP 1802 / 2014 privind modificarea OMFP 3055/2009 pentru aplicarea reglementărilor contabile conforme cu Directivele Europene, M.Of. 766bis/2009. Retrived from http://codfiscal.net/media/2015/01/OMFP-1802-2014-Reglementaricontabile-2015.pdf XXXXXAccessed 11.10.2016].

14. Legea 571/2003 privind Codul fiscal cu modificările şi completările ulterioare Retrived from $\mathrm{h}$ tp://www.cdep.ro/pls/legis/legis_pck.htp_act_text?idt=52436 XXXXXAccessed 9.10.2016].

15. Online platforms: Crestemidei.ro, Kazuu.ro, Multifinantare.ro, PotSiEu.ro,We-arehere.ro, Bursabinelui.ro XXXXXAccessed 3.11.2016]. 